\title{
Evaluation of swallowing pattern sound in patients with temporomandibular
}

\section{disorder}

Avaliação dos padrões sonoros dla deglutição em pacientes com desordem da articulação

temporomandibular

Evaluación del sonido del patrón de deglución en pacientes con trastorno temporomandibular

Katiane Regina Staszak Castilho ORCID: https://orcid.org/0000-0002-4140-8534

Tuiuti University of Paraná, Brazil

E-mail: katianestaszak@hotmail.com

Bianca Cavalcante-Leão

ORCID: https://orcid.org/0000-0002-6170-1914

Tuiuti University of Paraná, Brazil

E-mail: bianca.leao@utp.br

Ana Clara Gonçalves de Figueiredo

ORCID: https://orcid.org/0000-0003-4154-9991

Tuiuti University of Paraná, Brazil

E-mail: ana.figueiredo@utp.edu.br

Gloria Maria Cortz Ravazzi

ORCID: https://orcid.org/0000-0002-6574-9878

Tuiuti University of Paraná, Brazil

E-mail: gcortz87@hotmail.com

Bianca Simone Zeigelboim

ORCID: https://orcid.org/0000-0003-4871-2683

Tuiuti University of Paraná, Brazil

E-mail: bianca.zeigelboim@utp.br

Wagner Hummig

ORCID: https://orcid.org/0000-0003-1651-6610

Neurology Institute of Curitiba, Brazil

E-mail: waghum@hotmail.com

Rosane Sampaio Santos

ORCID: https://orcid.org/0000-0001-6400-5706

Tuiuti University of Paraná, Brazil

Jose Stechman-Neto

ORCID: https://orcid.org/0000-0002-0259-2420

Tuiuti University of Paraná, Brazil

E-mail: stechman1@gmail.com

\begin{abstract}
Objectives: The impairment of the temporomandibular joint and masticatory muscles has a negative impact on functions of the stomatognathic system, such as swallowing. Thus, an atypical swallowing pattern may contribute to the development of temporomandibular disorder (TMD). The aim of the present study was to evaluate acoustic aspects of swallowing and determine the occurrence of atypical swallowing dynamics. Methods: Sixty-two individuals [16 males $(25.8 \%)$ and 46 females $(74.2 \%)$; mean age $39.84( \pm 9.40)$; 47 with TMD and 15 without TMD] were evaluated using an ultrasound detector during the swallowing of three consistencies: liquid, pasty and solid. The acoustic signals were recorded and subsequently analyzed using the DeglutiSom ${ }^{\circledR}$ software. Results: The majority of the sample $(81 \%)$ with TMD presented atypical swallowing biodynamics, with a significantly greater frequency of food residuals for the three consistencies. The signal suggestive of aspiration was more frequent with the liquid consistency (37\% of the group). Conclusion: There is a relation between TMD and an atypical swallowing pattern, which underscores the need for the multidisciplinary evaluation of individuals with this disorder.
\end{abstract} Keywords: Deglutition; Temporomandibular joint dysfunction syndrome; Deglutition disorders. 


\begin{abstract}
Resumo
Objetivos: O comprometimento da articulação temporomandibular e dos músculos mastigatórios tem um impacto negativo sobre as funções do sistema estomatognático, tais como a deglutição. Assim, um padrão de deglutição atípico pode contribuir para o desenvolvimento da desordem temporomandibular (DTM). O objetivo do presente estudo é, portanto, avaliar os aspectos acústicos da deglutição e determinar a ocorrência da dinâmica atípica da deglutição. Metodologia: Sessenta e dois indivíduos [16 homens (25,8\%) e 46 mulheres (74,2\%); média de idade 39,84 ( \pm 9,40); 47 com DTM e 15 sem DTM] foram avaliados usando um detector de ultrassom durante a deglutição de três consistências: líquida, pastosa e sólida. Os sinais acústicos foram registrados e posteriormente analisados utilizando o software DeglutiSom ${ }^{\circledR}$. Resultados: A maioria da amostra (81\%) com TMD apresentou biodinâmica de deglutição atípica, com uma frequência significativamente maior de resíduos alimentares para as três consistências. $\mathrm{O}$ sinal sugestivo de aspiração foi mais frequente com a consistência líquida (37\% do grupo). Conclusão: Existe uma relação entre TMD e um padrão de deglutição atípico, o que ressalta a necessidade de uma avaliação multidisciplinar dos indivíduos com este distúrbio.
\end{abstract}

Palavras-chave: Deglutição; Síndrome da disfunção da articulação temporomandibular; Transtornos de deglutição.

\begin{abstract}
Resumen
Objetivos: La alteración de la articulación temporomandibular y de los músculos masticatorios repercute negativamente en las funciones del sistema estomatognático, como la deglución. Así, un patrón de deglución atípico puede contribuir al desarrollo del trastorno temporomandibular (TTM). El objetivo del presente estudio fue evaluar los aspectos acústicos de la deglución y determinar la aparición de una dinámica de deglución atípica. Métodos: Sesenta y dos individuos [16 varones $(25,8 \%)$ y 46 mujeres $(74,2 \%)$; edad media 39,84 ( $\pm 9,40)$; 47 con TTM y 15 sin TTM] fueron evaluados mediante un detector de ultrasonidos durante la deglución de tres consistencias: líquida, pastosa y sólida. Las señales acústicas fueron grabadas y posteriormente analizadas con el software DeglutiSom®. Resultados: La mayoría de la muestra $(81 \%)$ con TTM presentó una biodinámica de la deglución atípica, con una frecuencia significativamente mayor de residuos alimentarios para las tres consistencias. La señal sugestiva de aspiración fue más frecuente con la consistencia líquida (37\% del grupo). Conclusiones: Existe una relación entre el TTM y un patrón de deglución atípico, lo que subraya la necesidad de la evaluación multidisciplinar de los individuos con este trastorno.

Palabras clave: Deglución; Síndrome de la disfunción de articulación temporomandibular; Trastornos de deglución.
\end{abstract}

\title{
1. Introduction
}

Temporomandibular disorder (TMD) is a broad term used to identify problems involving the masticatory muscles, temporomandibular joint and associated structures. This condition is clinically characterized by pain, altered mandibular kinematics and joint sounds (Greene, Klasser \& Epstein, 2010).

The impairment of the temporomandibular joint and masticatory muscles often has a negative impact on functions of the stomatognathic system, such as speaking, breathing, chewing and swallowing, since these

structures actively participate in such processes (De Felicio, Melchior \& Da Silva, 2010; Ferreira, Da Silva \& De Felício, 2009; Ferreira, Sforza, Rusconi, Castelo \& Bommarito, 2019; Gilheaney, Zgaga, Harpur, Sheaf, Kiefer, Béchet \& Walshe, 2017). As occurs to minimize the sensation of pain, a protective mechanism alters the normal functioning of the stomatognathic system (Maffei, Mello, Biase, Pasetti, Camargo, Silverio \& Gonçalves, 2012; Weber, Correa, Bolzan, Ferreira, Soares \& Silva, 2013; Williamsom, Hall \& Zwemer, 1990), the most affected functions of which are chewing and swallowing (Ciavarella, Tepedino, Laurenziello, Guida, Troiano, Montaruli, Illuzzi, Chimenti \& Lo Muzio, 2018; Ferreira et al., 2019; Fassicollo, Machado, Garcia \& Felício, 2019; Gilheaney, Stassen \& Walshe, 2018; Radke, Kull \& Sethi, 2014).

By definition, swallowing is a set of coordinated muscle contractions that move the food bolus from the oral cavity through the esophagus to the stomach. For this to occur, the lips must be closed, sealing the oral cavity, and the teeth must be in maximum intercuspation to stabilize the mandible. The stabilization of the mandible is fundamental to the proper contraction of the suprahyoid and infrahyoid muscles. These muscles control the hyoid bone, which is necessary for swallowing (Maffei et al., 2012).

In an atypical swallowing pattern, the tongue is interposed between the teeth and the contraction of the perioral and 
chin muscles is required to propel the food from the oral cavity to the pharynx (De Felicio et al., 2010; Maffei et al., 2012). Thus, an atypical swallowing pattern may be a contributing factor to the development of TMD, as the constant interposition of the tongue alters the balance and stability of the maxillomandibular relation (Maffei et al., 2012; Marim, Machado, Trawitzki \& de Felício, 2019; Souza, Correia, Stefani \& Oliveira, 2004).

Most studies relating TMD to inadequate swallowing patterns (Barbosa, Alcantara, Pereira, Consoni \& Conti, 2012; Goldstein, Last \& Salerno, 1997; Maffei et al., 2012; Weber et al., 2013) only mention the oral phase of swallowing, for which observational studies (Bianchini, 1999; Ferreira, Da Silva \& De Felício, 2009; Weber et al., 2013) have recorded characteristics (head movements, perioral muscle contractions and tongue interposition) during the swallowing of different food consistencies. Electromyography of the masticatory muscles is another analysis method described in the literature (Goldstein et al., 1997; Williamsom et al., 1990).

The pharyngeal phase of swallowing has been studied little in patients with TMD. This analysis could be performed using video-assisted fluoroscopy during the swallowing of foods with different liquid textures blended with barium sulfate, which enables the analysis of swallowing and identifying compensatory movements during chewing (Maffei et al., 2012).

The ultrasound detector is considered to be a promising diagnostic and therapeutic monitoring method for the pharyngeal phase of swallowing due to its low cost and noninvasive nature (Enz, Vaz, M. C. A. Nunes, Rosa, J. A. Nunes, Marques \& Santos, 2021). Studies involving an ultrasound detector for the capture of swallowing sounds have been conducted with both healthy adults and patients with neurogenic oropharyngeal dysphagia (Kuhl, Eicke, Dieterich \& Urban, 2003; Söder \& Miller, 2002). However, no previous studies have employed this method on individuals with TMD.

As an atypical swallowing pattern may be both a cause and consequence of TMD, there is a need to investigate this relation so that due attention can be given during the clinical evaluations of patients by a multidisciplinary team to arrive at the most adequate treatment for each patient. Therefore, the aim of the present study was to evaluate abnormalities in the biodynamics of swallowing (presence of residuals and signs suggestive of aspiration) in the pharyngeal phase through an acoustic analysis in individuals with and without TMD using an ultrasound detector.

\section{Materials and Methods}

This study received approval from the local ethics committee (certificate number: 73969417.4.0000.8040), and it is a cross-sectional, observational, case-control study (Freire \& Pattusi, 2018). and involved the participation of male and female individuals between 19 and 64 years of age who signed a statement of informed consent. The case group (with TMD) was selected over a four-day period of screening for TMD and orofacial pain using Research Diagnostic Criteria for Temporomandibular Disorders (RDC/TMD) (Dworkin \& Leresche, 1992), which includes a 31-item self-administered questionnaire as well as a 10-item form and specifications for the physical examination. The individuals in the control group were recruited from the dental clinic of the same university over the same four-day period and did not fulfil the requirements for TMD using the criteria applied to the case group.

The sample was composed of 62 individuals -47 with one or more signs of muscle and/or joint TMD (case group) and 15 without TMD (control group). The test power for the sample examined was 92\% (Fleiss, 1981).

All participants were submitted to an evaluation of swallowing sounds using the portable Angel Sounds ultrasound detector (Jumper $\left.{ }^{\circledR}\right)$. This device is battery powered and has a transducer coupled to an earphone output, recorder or computer (Figure 1). All individuals received the same three consistencies for the evaluation: liquid (30 $\mathrm{ml}$ of water); pasty (30 $\mathrm{ml}$ of water with food thickener (Resource ${ }^{\circledR}$, Nestlé Health Science $\left.{ }^{\circledR}\right)$; and solid (cookie with strawberry-flavored filling (Bono®). 
Figure 1. Ultrasound detector- transducer coupled to an earphone output and a computer.

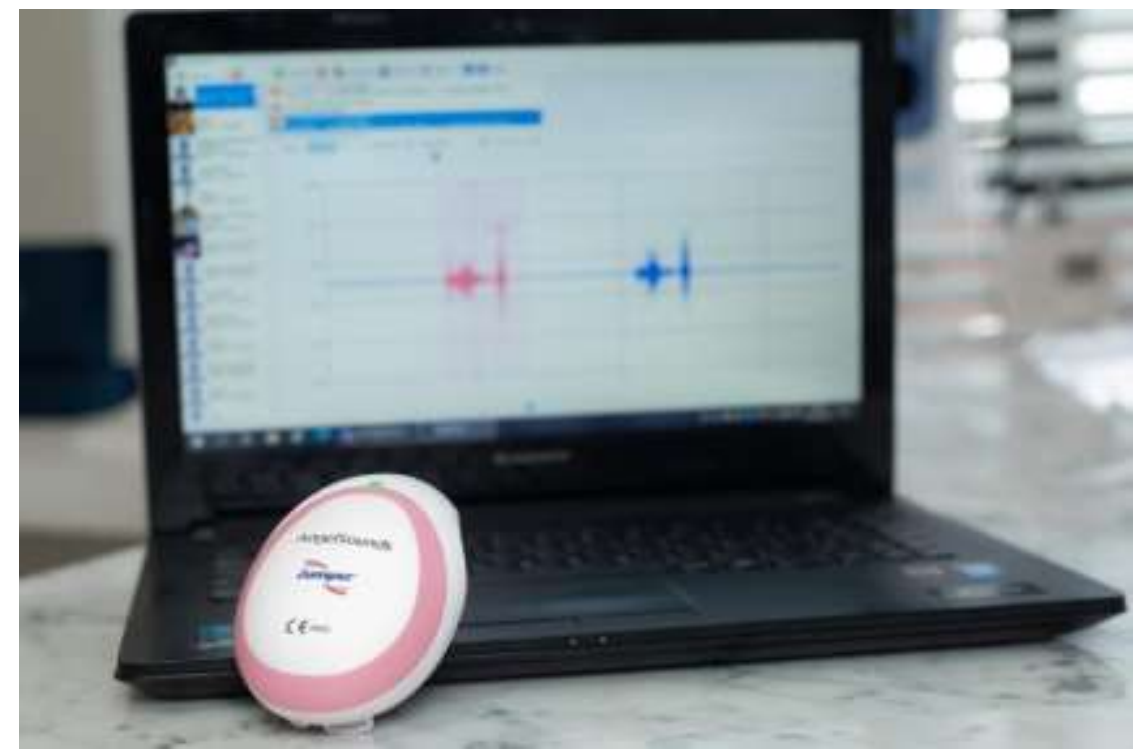

Source: Authors.

Figure 1 refers to the $3 \mathrm{MHz}$ doppler equipment destined for the caption of swallowing sounds and DeglutiSom ${ }^{\circledR}$ software for analysis and identification of swallows.

To capture the swallowing sounds, the participant remained seated on a chair with the cervical region in ventral flexion (simulating the position during a normal meal) and free access to the neck. The ultrasound device was positioned in the right lateral region of the neck at the lateral edge of the trachea and immediately below the cricoid cartilage, which is considered by best position for cervical auscultation (Takahashi, Groher \& Michi, 1994). The ultrasound detector was coupled to a laptop computer. The acoustic signals were recorded and subsequently analyzed using the DeglutiSom ${ }^{\circledR} \operatorname{software}$.

\section{Results}

Sixty-two individuals (16 males $(25.8 \%)$ and 46 females $(74.2 \%)$; mean age: $39.84( \pm 9.40)]$ participated in the study. Forty-seven had TMD (six with muscle TMD, nine with joint TMD and 32 with mixed TMD) and 15 were without TMD according to the RDC/TMD. The analysis of the swallowing sounds in the pharyngeal phase involved the determination of the incidence of residuals and signals suggestive of aspiration with the three consistencies (liquid, pasty and solid) in the individuals with and without TMD (Table 1). The biodynamics of swallowing were also analyzed, and the results are displayed in Table 2. 
Table 1. Occurrence of residuals and signals suggestive of aspiration with the three consistencies according to the presence/absence of TMD $(n=62)$.

\begin{tabular}{|c|c|c|c|c|c|}
\hline & & & $\begin{array}{l}\text { With } \\
\text { TMD }\end{array}$ & $\begin{array}{l}\text { Without } \\
\text { TMD }\end{array}$ & $\mathrm{p}^{*}$ \\
\hline \multirow{6}{*}{ Liquid } & \multirow{3}{*}{ Residuals } & Yes & 21 & 2 & \multirow{3}{*}{$0.029 *$} \\
\hline & & & & & \\
\hline & & No & 26 & 13 & \\
\hline & \multirow{3}{*}{ Signal suggestive of aspiration } & Yes & 16 & 0 & \multirow{3}{*}{$0.007^{* *}$} \\
\hline & & & & & \\
\hline & & No & 31 & 15 & \\
\hline \multirow{6}{*}{ Pasty } & \multirow{3}{*}{ Residuals } & Yes & 22 & 0 & \multirow{3}{*}{$0.001 * *$} \\
\hline & & & & & \\
\hline & & No & 25 & 15 & \\
\hline & \multirow{3}{*}{ Signal suggestive of aspiration } & Yes & 10 & 0 & \multirow{3}{*}{0.100} \\
\hline & & & & & \\
\hline & & No & 37 & 15 & \\
\hline \multirow{6}{*}{ Solid } & \multirow{3}{*}{ Residuals } & Yes & 33 & 5 & \multirow{3}{*}{$0.011 *$} \\
\hline & & & & & \\
\hline & & No & 14 & 10 & \\
\hline & \multirow{3}{*}{ Signal suggestive of aspiration } & Yes & 8 & 0 & \multirow{3}{*}{0.181} \\
\hline & & & & & \\
\hline & & No & 39 & 15 & \\
\hline
\end{tabular}

*chi-squared test. ** Fisher's exact test. Source: Authors.

A total of 15 patients (44\%) had a suggestive sign of aspiration, being considered significant only for the liquid consistency, 12 patients $(35 \%)$.

Table 2. Abnormal biodynamics according to presence/absence of TMD $(n=62)$.

\begin{tabular}{|c|c|c|c|c|}
\hline & & $\begin{array}{l}\text { With } \\
\text { TMD }\end{array}$ & $\begin{array}{c}\text { Without } \\
\text { TMD }\end{array}$ & $\mathrm{p}^{*}$ \\
\hline \multirow{3}{*}{ Abnormal biodynamics } & Yes & 38 & 7 & \multirow{3}{*}{0.010} \\
\hline & & & & \\
\hline & No & 9 & 8 & \\
\hline
\end{tabular}

*chi-squared test. Source: Authors. 
The most common change in swallowing biodynamics was the presence of food residues, $85.3 \%$ of the sample showed changes in one or more of the three consistencies.

The individuals with TMD had a 2.07-fold greater likelihood of exhibiting atypical swallowing biodynamics compared to those without TMD $(\mathrm{OR}=0.207 ; 95 \% \mathrm{CI}: 0.060$ to 0.722$)$.

\section{Discussion}

Swallowing is one of the most commonly altered orofacial functions in individuals with TMD (Ciavarella et al., 2018; Fassicollo et al., 2019; Ferreira et al., 2009; Ferreira et al., 2019; Gilheaney et al., 2017; Gilheaney et al., 2018; Marim et al., 2019). In an observational study of the oral phase of swallowing, abnormalities were found in $78.75 \%$ of individuals with TMD (Ferreira et al., 2009). In contrast, a similar study found that only $19.6 \%$ of individuals with TMD exhibited signs of atypical swallowing (Bianchini, 1999). In a recent systematic review, only $9.3 \%$ of patients had swallowing difficulties in the oral phase even though presenting with signs and symptoms of TMD (Gilheaney, Béchet, Kerr, Kenny, Smith, Kouider, Kidd \& Walshe, 2018), such as other systematic review in patients with TMD and Rheumatoid Arthritis (Gilheaney et al., 2017).

Abnormalities in the swallowing pattern may be the consequence of the structural and functional imbalance found in individuals with TMD caused by a nociceptive stimulus (Williamsom et al., 1990). An atypical swallowing pattern may also be a contributing factor to the development of TMD, as the constant interposition of the tongue and abnormal positioning of the head when swallowing alters the maxillomandibular relation (Ferreira et al., 2009; Maffei et al., 2012; Rosa, Bueno, Migliorucci, Brasolotto, Genaro, \& Berretin-Felix, 2020), which may be considered an etiological, perpetuating or aggravating factor of the structural change (Goldstein et al., 1997; Souza et al., 2004). Thus, the present findings may lead to the recognition of the atypical biodynamics of the pharyngeal phase of swallowing in individuals with TMD to enable a better diagnosis and consequently more adequate treatment.

Among the individuals with TMD in the present study, $81 \%$ presented atypical swallowing biodynamics in the pharyngeal phase. A similar finding (70\% of the sample) has been reported in patients with severe TMD (Maffei et al., 2012) and this result is in agreement with observational studies of the oral phase of swallowing (Ciavarella et al., 2018; Ferreira et al., 2009; Ferreira et al., 2019; Marim et al., 2019).

The most prevalent alteration in the biodynamics of swallowing was the presence of food residuals, which, to some extent, can be considered a common finding in the biodynamics of swallowing. What is noteworthy in the present study, however, is the high prevalence found in the group with TMD. In a previous study involving the use of video-assisted fluoroscopy in patients with severe TMD, the persistence of food residuals was found in $40 \%$ of patients and the authors suggest that orofacial pain stemming from this disorder induces compensatory adjustments to execute the function of swallowing (Maffei et al., 2012).

The interposition of the tongue and inadequate lip seal are the most common characteristics of the oral phase of swallowing found in individuals with TMD (Barbosa et al., 2012; Ferreira et al., 2009; Marim et al., 2019; Souza et al., 2004; Weber et al., 2013), likely due to alterations in dental intercuspation and/or the temporomandibular joint (Ferreira et al., 2009) in an attempt to avoid discomfort and minimize pain (Barbosa et al., 2012; Williamsom et al., 1990). In an observational test of swallowing in the oral phase with different liquid and solid consistencies, an association was found between TMC and inadequate swallowing only during the ingestion of liquids (76.7\%) (Barbosa et al., 2012). In the present study, the ultrasound detector revealed significant alterations for the three consistencies tested and the greatest number of participants with food residuals was found when the solid food was tested. A part of the individuals with TMD reported difficulty shredding the food due to muscle and/or joint fatigue, demonstrating the inefficiency of chewing during the test with the solid food. 
The small sample size did not enable the establishment of an association between altered swallowing biodynamics and a specific type of TMD. Among the nine patients without altered swallowing biodynamics, four were classified with joint TMD and five were classified with mixed (joint and muscle). Moreover, seven of these individuals had low pain intensity according to the RDC/TMD, which lends support to the hypothesis that alterations are associated with a compensatory mechanism in an attempt to avoid pain during the functions of chewing and swallowing. Future studies should be conducted with a larger and segmented sample to enable establishing the association between a specific type of TMD and atypical swallowing biodynamics.

The present findings underscore the importance of gathering information on the occurrence of choking and coughing during meals as well as difficulty chewing and shredding foods when taking the patient history. Moreover, an ultrasound detector enables a rapid, low-cost analysis of the swallowing pattern that can easily be included in the routine clinical evaluation.

\section{Conclusion}

The evaluation of swallowing sounds revealed atypical swallowing biodynamics in individuals with TMD for the three consistencies tested, with the presence of food residuals the most common finding. A signal suggestive of aspiration was only significant when the liquid was used. These findings underscore the importance of a multidisciplinary evaluation of such patients for the proper diagnosis of TMD and definition of the treatment plan.

It is important to emphasize that the use of this method for residue identification and/or dysphagia tracking, needs further studies. In addition, larger sample sizes and blind evaluators should be considered in future research to increase the reliability of the proposed method.

\section{References}

Barbosa, J. S.; Alcantara, A. M.; Pereira, C. A.; Consoni, F. M. C. \& Conti, P. C. R. (2012). A deglutição inadequada está associada à presença de dor miofascial mastigatória? Rev Dor. abr-jun; 13(2): 132-6

Bianchini, E. M. G. (1999). Disfunção da articulação temporomandibular: relações com a deglutição e a fala. Rev Dent Press Ortodon Ortoped Facial. 4(5): 55-60.

Marim, G. C.; Machado, B. C. Z.; Trawitzki, L. V. L. \& Felício, C. M. (2019). Tongue strength, masticatory and swallowing dysfunction in patients with chronic temporomandibular disorder. Physiology \& Behavior. 112616. 10.1016/j.physbeh.2019.112616.

Ciavarella, Domenico \& Tepedino, Michele \& Laurenziello, Michele \& Guida, Laura \& Troiano, Giuseppe \& Montaruli, Graziano \& Illuzzi, Gaetano \& Chimenti, Claudio \& Lo Muzio, Lorenzo. (2018). Swallowing and Temporomandibular Disorders in Adults. Journal of Craniofacial Surgery. 29. 1. 10.1097/SCS.0000000000004376.

De Felicio, C. M.; Melchior, M. O. \& Da Silva, M. A. (2010). Effects of orofacial myofunctional therapy on temporomandibular disorders. J Craniomandib Pract. 28(4): 249-259.

Dworkin, S. F. \& Leresche, L. (1992). Research diagnostic criteria for temporomandibular disorders review, examinations and specifications, critique. $J$ Craniomandib Disord: 6(4): 301-55.

Enz, V. C. Q.; Vaz, A. R. C.; Nunes, M. C. A.; Rosa, M. O.; Nunes, J. A.; Marques, J. M. \& Santos, R. S. Accuracy of Acoustic Evaluation of Swallowing as a Diagnostic Method of Dysphagia in Individuals Affected by Stroke: Preliminary Analysis. Dysphagia (2021). https://doi.org/10.1007/s00455-021-10358-5

Fassicollo, C. E.; Machado, B. C. Z.; Garcia, D. M. \& Felício, C. M. (2019). Swallowing changes related to chronic temporomandibular disorders. Clin Oral Invest 23: 3287. https://doi.org/10.1007/s00784-018-2760-z

Ferreira, C. L.; Da Silva, M. A. \& De Felício, C. M. (2009). Orofacial myofunctional disorders in subjects with temporomandibular disorders. J Craniomandib Pract. 27(4): 268-74.

Ferreira, C. L. P.; Sforza, C.; Rusconi, F. M. E.; Castelo, P. M. \& Bommarito, S. (2019). Masticatory behavior and chewing difficulties in young adults with temporomandibular disorders. Journal of Oral Rehabilitation. 46. 10.1111/joor.12779.

Fleiss J.L. (1981). Statistical Methods for Rates and Proportions. John Wiley \& Sons. 
Freire, M. C. M. \& Pattusi, M. P. Tipos de estudo, p. 113-117. In: Medodologia científica:ciência, ensino e pesquisa/Organizaor. Carlos Estrela 3 edição Porto Alegre: Artes Médicas, 2018.

Gilheaney, O.; Béchet, S.; Kerr, P.; Kenny, C.; Smith, S.; Kouider, R.; Kidd, R. \& Walshe, M. (2018). The prevalence of oral stage dysphagia in adults presenting with temporomandibular disorders: a systematic review and meta-analysis. Acta Odontol Scand. 76(4); 1-11.

Gilheaney, Orla \& FA. Stassen, Leo \& Walshe, Margaret. (2018). The prevalence, nature, and management of oral stage dysphagia in adults with temporomandibular joint disorders: Findings from an Irish cohort. Journal of Oral and Maxillofacial Surgery. 76. 10.1016/j.joms.2018.01.036.

Gilheaney, O.; Zgaga, L.; Harpur, I.; Sheaf, G.; Kiefer, L.; Béchet, S. \& Walshe, M. (2017). The Prevalence of Oropharyngeal Dysphagia in Adults Presenting with Temporomandibular Disorders Associated with Rheumatoid Arthritis: A Systematic Review and Meta-analysis. Dysphagia. 32. 10.1007/s00455-0179808-0.

Goldstein, L. B.; Last, F. C. \& Salerno, V. M. (1997). Prevalence of hyperactive digastric muscles during swallowing as measured by electromyography in patients with myofascial dysfunction syndrome. Funct Orthod; 14(3): 18-22.

Greene, C. S.; Klasser, G. D. \& Epstein, J. B. (2010). Revision of the American Association of Dental Research's Science Information Statement about Temporomandibular Disorders. J Can Dent Assoc.76:a115.

Kuhl, V.; Eicke, B. M.; Dieterich, M. \& Urban, P. P. (2003). Sonographic analysis of laryngeal elevation during swallowing. J Neurol. 250(3):333-7. http://dx.doi.org/10.1007/s00415-003-1007-2

Maffei, C.; Mello, M. M.; Biase, N. G.; Pasetti, L.; Camargo, P. A. M.; Silverio, K. C. A. \& Gonçalves, M. I. R. (2012). Avaliação Videofluoroscópica Da Mastigação E Deglutição Em Indivíduos Com Disfunção Temporomandibular. Braz J Otorhinolaryngol. 78 (4): $24-28$.

Radke, J., C.; Kull, R. S. \& Sethi M. S. (2014). Chewing movements altered in the presence of temporomandibular joint internal derangements, CRANIO®, 32:3, 187-192, DOI: 10.1179/0886963413Z.00000000028

Rosa, R. R.; Bueno, M. d. R. S.; Migliorucci, R. R.; Brasolotto, A. G.; Genaro, K. F., \& Berretin-Felix, G. (2020). Tongue function and swallowing in individuals with temporomandibular disorders. Journal of Applied Oral Science, 28. https://doi.org/10.1590/1678-7757-2019-0355

Söder, N. \& Miller, N. (2002). Using ultrasound to investigate intrapersonal variability in durational aspects of tongue movement during swallowing. Dysphagia. 17(4):288-97. http://dx.doi.org/10.1007/s00455-002- 0071-6.

Souza, D. M. F.; Correia, F. A. Z.; Stefani, F. M. \& Oliveira, M. F. R. (2004). Prevalência das principais alterações nas funções estomatognáticas de respiração, mastigação e deglutição em pacientes portadores de disfunção temporomandibular. J Bras Fonoaudiol; 5(19): 84-87.

Takahashi, K.; Groher, M. E. \& Michi, K. (1994). Methodology for detecting swallowing sounds. Dysphagia; 9: 54-96.

Weber, P.; Correa, E. C. R.; Bolzan, G. P.; Ferreira, F. S.; Soares, J. C. \& Silva, A. M. T. (2013). Mastigação e deglutição em mulheres jovens com desordem temporomandibular. In CoDAS. 375-80.

Williamsom, E. H.; Hall, J. T. \& Zwemer, J. D. (1990). Swallowing patterns in human subjects with and without temporomandibular dysfunction. Am J Orthod Dentofacial Orthop; 98 (6):507-11. 